\title{
Fallecimiento del doctor Jacques de Rougemont Miembro honorario del CICR
}

El pasado 24 de diciembre de 1988, el CICR recibió con profunda tristeza la noticia del fallecimiento del doctor Jacques F. de Rougemont, Miembro honorario del CICR.

E1 doctor de Rougemont, elegido miembro del CICR en 1967, fue miembro del Consejo de la Presidencia de 1968 a 1971 y, desde 1987, Miembro honorario.

En el curso de su larga y fecunda labor al servicio del CICR, formó parte de varias comisiones y grupos de trabajo y efectuó numerosas misiones para la Institución, en particular en Polonia en favor de las víctimas de experiencias pseudomédicas en los campos de concentración nazis. Las relaciones de confianza que supo entablar en Polonia propiciaron una de las más importantes acciones de difusión del derecho internacional humanitario y, en 1982, permitieron que el CICR visitara a las personas detenidas a causa de los acontecimientos de diciembre de 1981.

El CICR rinde un emocionado homenaje a la memoria del doctor de Rougemont, al que asocia a su hijo Quentin, delegado del CICR fallecido durante una misión en Angola, el año 1986. 